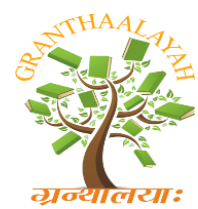

INTERNATIONAL JOURNAL OF RESEARCH GRANTHAALAYAH

A knowledge Repository

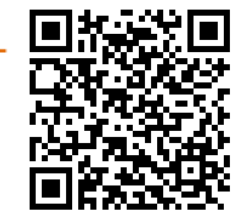

Management

\title{
INDIAN CORPORATE FINANCIAL REPORTING SYSTEM: A STUDY ON THE CASH FLOWS OF SELECTED PRIVATE ENTERPRISES
}

\author{
Dr. Santanu Kumar Das *1 \\ *1 Assistant Professor, P.G. Department of Business Administration, Kalam Institute of \\ Technology, Berhampur, Odisha, INDIA
}

\begin{abstract}
Corporate financial reporting plays an important role in growing phenomenon of Privatization. The present study is based on the reports of Private Enterprises for three years. Findings revealed that the companies were presenting their annual reports. A privately owned enterprise refers to a commercial enterprise that is owned by private investors, shareholders or owners. The recent trend in financial reporting includes presentation and discloser of accounting aspect, corporate governance, corporate social responsibility and narrative reporting. The present paper will examine the cash flow statements of Maharastra Scooters Ltd., Tata Chemicals Ltd. and TVS Srichakra. In corporate financial reporting cash flow statement tells us the net cash flow activities, particularly its operating, investing and financial activities. These indications are helpful to analyze cash flow. This explains the sources and applications of liquidity of company. Keeping the importance of financial reporting in modern world the present paper attempts to analyzed and evaluate the financial reporting system in some selected units of private enterprises in India.
\end{abstract}

Keywords:

Privatization, Corporate governance, Financial reporting, Private enterprises.

Cite This Article: Dr. Santanu Kumar Das, "INDIAN CORPORATE FINANCIAL REPORTING SYSTEM: A STUDY ON THE CASH FLOWS OF SELECTED PRIVATE ENTERPRISES" International Journal of Research - Granthaalayah, Vol. 4, No. 1 (2016): 3542.

\section{INTRODUCTION}

A privately held company or close corporation is a business company owned either by nongovernment organizations or by a relatively small number of shareholders or company members which does not offer or trade its company stock (shares) to the general public on the stock market exchanges, but rather the company's stock is offered, owned and traded or exchanged privately. More ambiguous terms for a privately held company are unquoted company and unlisted company. 
Privately held companies generally have fewer or less comprehensive reporting requirements and obligations for transparency, via annual reports, etc. than publicly traded companies do. For example, in the United States, unlike in Europe privately held companies are not generally required to publish their financial statements. By not being required to disclose details about their operations and financial outlook, private companies are not forced to disclose information that may potentially be valuable to competitors and can avoid the immediate erosion of customer and stakeholder confidence in the event of financial duress. Further, with limited reporting requirements and shareholder expectations, private firms are afforded a greater operational flexibility by being able to focus on long term growth rather than quarterly earnings. In addition, private company executives may steer their ships without shareholder approval, allowing them to take significant action without delays.

Private companies may be called corporations, limited companies, limited liability companies, unlimited companies or other names, depending on where and how they are organized and structured. In the United States, but not generally in the United Kingdom, the term is also extended to partnerships, sole proprietorships or business trusts. Each of these categories may have additional requirements and restrictions that may impact reporting requirements, income tax liabilities, governmental obligations, employee relations, marketing opportunities, and other business obligations and decisions.

\section{NEED OF THE STUDY}

Corporate financial reporting is a communication system between an entity and target audience. It assists the investors to select the best portfolio for their investments. Besides investors, the disclosure of financial information also benefits the lenders, suppliers, creditors, customers, financial analysts, brokers, underwriters, stock exchange authorities, government, financial press, labor unions, trade associations and academicians etc.

\section{IMPORTANCE OF THE STUDY}

The present study is very important to Indian economic. In India Corporate Financial Reporting system supported by good governance, high quality standards and sound regulatory framework is the key to economic development. Financial reporting provides company's financial information to its investors and creditors. In a globalised world, capital providers, investors and creditors are interested to know the financial conditions for both the safety and profitability of their investments. An appropriate financial reporting system incorporates sound accounting principles reflects a true and fair view of the financial health of the company while ensuring legally enforceable accountability, So researcher felt the present study is more important and more relevance to study.

\section{OBJECTIVES OF THE STUDY}

1. To study the corporate finance reporting system in India context.

2. To study the corporate financial reporting of Private Enterprises in India.

3. To analysis the Cash Flow Statements of selected Private Entrepreneurships.

4. To evaluate the reporting system of selected Private units and to draw conclusion about the liquidity position. 


\section{RESEARCH METHODOLOGY}

The study is mainly based mainly on secondary data and collecting information. The sources of the secondary data includes annual reports, books, internet search, articles and journals among others such as the Hindu, Indian Express, ext., were also used for the purpose of collection the information's. This helped to identify how others have defined and measured key concepts, the data sources that of others used. The Study period covers three years commencing 2011-12 ending to 2013-14.

For the present study three companies from private sector selected on the basis of random.

\section{LIMITATIONS OF THE STUDY}

1. Companies included in the study came into existence in between the period of study, so there was difficulty in same sample size.

2. Some private finance companies are the subsidiaries of the holding companies. So their annual reports were available as part of the main annual report of the holding company.

\section{MAHARASHTRA SCOOTERS (MSL)}

Maharashtra Scooters (MSL) was incorporated on June 11, 1975. It holds 3.35\% stake in Bajaj Auto in addition to $4.88 \%$ stake in Bajaj Auto Finance. It is a joint sector enterprise promoted by Western Maharashtra Development Corporation (27\%) and Bajaj Auto (24\%). The company assembled geared scooters, but due to non-availability of CKD packs from Bajaj Auto, the company stopped production of geared scooters in April 2006. MSL has managerial and technical agreement with Bajaj Auto for production of scooters. Scooter brands included Chetak, Super and Priya. The company has its plants in Waluj and Akurdi. The registered office of the company is at Bajaj Auto, Mumbai - Pune Road, Akurdi, Pune - 411035 and Maharashtra.

\section{CASH FLOW OF MAHARASTRA SCOOTERS}

In financial accounting, a cash flow statement, also known as statement of cash flows, is a financial statement that shows how changes in balance sheet accounts and income affect cash and cash equivalents and breaks the analysis down to operating, investing and financing activities. Essentially, the cash flow statement is concerned with the flow of cash in and out of the business. The statement captures both the current operating results and the accompanying changes in the balance sheet. As an analytical tool, the statement of cash flows is useful in determining the short-term viability of a company, particularly its ability to pay bills. International Accounting Standard 7 (IAS7), is the international accounting standard that deals with cash flow statements.

\section{TATA CHEMICALS LIMITED}

Tata Chemicals Limited is one of the largest chemical companies in India with significant operations in India and Africa. The company is an Indian global company with interests in chemicals, crop nutrition and consumer products head quartered in Mumbai, India. Tata Chemicals is a subsidiary of Tata Group conglomerate.

Tata Chemicals has the second largest soda ash production capacity plant in India. This was the second soda ash plant built in India by Shri Kapilram Vakil that started operating in the year 
1944. The township Mithapur derives its name from "Mith" which means salt in Gujrati language. Tata Chemicals has owned Brunner Mond since 2006; A United Kingdom-based Chemical Company with operations in Magadi (Kenya) and General Chemicals in Unirica.

On 27 March 2008, Tata Chemicals Ltd. acquired 100 percent stake in US based General Chemical Industrial Products Inc (GCIP) for USS1.05 billion to become the world's second largest maker of soda ash. With all these acquisitions, combined capacity of production has increased to around 5.17 million tons of soda ash. In April 2010, Tata Chemicals acquired 25\% stake in ammonia-urea fertilizer complex in Gabon for US\$290 million. The first phase of the plant will have a full operational capacity of 2.2 billion tons of ammonia and 3.85 billion tons of urea per day.

\section{TVS SRICHAKRA LIMITED}

TVS Srichakra Ltd., one of India's leading two \& three-wheeler tyre manufacturers. Being a part of TVS Auto Ancillary Group (Turn-over of USD 6.0 billion) founded by T.V. Sundaram Iyengar, we continue to honour the value system and the rich heritage of our parent company. Over 30 years, we've leveraged our expertise to ensure your every ride is as safe as it is sensible.

With state-of-the-art manufacturing units at Madurai (Tamil Nadu) and Rudrapur (Uttrakhand), spread over 2.9 lakh sq. meters, we manufacture a prolific range of tyres: Two \& Three-wheeler tyres, Industrial pneumatic tyres, Farm and implement tyres, Skid steer tyres, multipurpose tyres, Floatation tyres. Being the leading choice of Original Equipment Manufacturers across India, we also supply our products to major vehicle manufacturers across country: Atul Auto Limited, Bajaj Auto, Hero Moto Corp Limited, Honda Motors Cycles \& Scooters India, India Yamaha Motor Pvt. Ltd, LML, Mahindra 2wheelers, Piaggio, TVS Motor Company Ltd.

It caters to domestic after-market with a strong support network of over 2400 dealers and 34 depots. Today, TVS Tyres cruises across the globe as well, extending its presence through export to USA, Europe, South America, Africa and Australia.

\section{ANALYSIS AND INTERPRETATION OF DATA}

\section{NET PROFIT ANALYSIS}

Every Company in the corporate world is formulating all its policies and developing its strategies to earn profits and to maximize the profitability position in future. Profit is quantum of profit earned and profitability includes profit plus capacity of the firm to earn profit in future. Analysis of the profit results to judge the performance of the company and its efficiency in effective utilization of funds. The comparative performance in profit before tax of sample selected units is shown below:

Table 1: Table Showing Comparison of Net Profit before Tax (Rs. In Crores)

\begin{tabular}{|l|l|l|l|l|l|l|}
\hline \multirow{2}{*}{ Years } & \multicolumn{2}{|l|}{ Maharashtra Scooter } & \multicolumn{2}{|l|}{ Tata Chemical Ltd. } & \multicolumn{2}{|c|}{ TVS Srichakra } \\
\cline { 2 - 7 } & Net Profit & \% of Change & Net Profit & $\begin{array}{l}\text { \% of } \\
\text { Change }\end{array}$ & $\begin{array}{l}\text { Net } \\
\text { Profit }\end{array}$ & $\begin{array}{l}\text { \% of } \\
\text { Change }\end{array}$ \\
\hline $2011-12$ & -6.49 & -- & 764.35 & -- & 54.75 & -- \\
\hline $2012-13$ & 48.84 & $85.25 \%$ & 825.37 & $7.98 \%$ & 47.27 & $(13.66 \%)$ \\
\hline
\end{tabular}




\begin{tabular}{|c|c|c|c|c|c|c|}
\hline 2013-14 & 47.60 & $(2.54 \%)$ & 568.88 & $(31.07 \%)$ & 55.92 & $18.30 \%$ \\
\hline
\end{tabular}

The above table shows the actual Net profit before tax and its percentage of growth of fall during the year 2011-12 to 2013-14. The highest growth in profit was recorded by Maharashtra Scooter ltd in 2012-13 i.e. $82.25 \%$ over its previous year. During the same year Tata Chemical Ltd. Growth was $7.98 \%$ and TVS Srichakra company incurred loss resulted fall in profit before tax i.e. $13.66 \%$. The quantum of profit earned by Tata Chemical Ltd. in all three years was large i e it was ranged in between 568.88Crors to 825.37crors as compared to other sample units selected for the study. It can be found from the dame table that both Maharashtra Scooter and Tata Chemical ltd showed negative percentage of growth in profit i.e. $2.54 \%$ and $31.07 \%$ respectively. From the above it can be concluded that the performance of sample units during the period of study is not consistent.

\section{ANALYSIS OF NET CASH FLOWS}

Analysis of cash flows (inflows and outflows of cash) helps to test the company's liquidity position to meet all its short term liabilities in time. As per as cash flows are concerned here it means cash flows includes operating, financial and non-operating activity. The year wise net cash flows and its change in percentage over previous years are given below in table 2.

Table 2: Table Showing Comparative Net Cash Flows from Operative Activities (Rs. In Crores)

\begin{tabular}{|c|c|c|c|c|c|c|}
\hline \multirow{2}{*}{ Years } & \multicolumn{2}{|c|}{ Maharashtra Scooter } & \multicolumn{2}{|c|}{ Tata Chemical Ltd. } & \multicolumn{2}{|c|}{ TVS Srichakra } \\
\hline & $\begin{array}{ll}\text { Net } & \text { Cash } \\
\text { Flow } & \end{array}$ & $\%$ of Change & $\begin{array}{ll}\text { Net } & \text { Cash } \\
\text { Flow } & \end{array}$ & $\begin{array}{l}\% \text { of } \\
\text { Change }\end{array}$ & $\begin{array}{l}\text { Net } \\
\text { Cash } \\
\text { Flow }\end{array}$ & \% of Change \\
\hline 2011-12 & 340.73 & -- & -45.35 & -- & 91.97 & -- \\
\hline $2012-13$ & -297.83 & $(187.41 \%)$ & -7.55 & $83.35 \%$ & 192.36 & 109.16 \\
\hline 2013-14 & 1441.36 & $583.96 \%$ & -5.69 & $24.64 \%$ & 14.77 & (92.32) \\
\hline
\end{tabular}

It can be seen in the above table that in 2012-13 the net cash inflows of Maharashtra Scooter limited and Tata chemical limited were shown negative cash inflows which means cash outflow was more than cash inflows i.e $187.41 \%$ and $83.35 \%$ respectively. TVS Srichakra has negative percentage of change in the year 2013-14 i.e 92.32\%. It also come to know from the same table that during the study period Tata Chemical limited has negative net cash inflows it was decreased from 45.35Crors to 5.69crors. 
Table 3: Table Showing Comparative Net Cash from Operating and investing Activities (Rs. In Crores)

\begin{tabular}{|l|l|l|l|l|l|l|l|l|l|}
\hline Years & Maharashtra Scooter & \multicolumn{2}{l|}{ Tata Chemical Ltd. } & \multicolumn{2}{l|}{ TVS Srichakra } \\
\hline & $\begin{array}{l}\text { Operating } \\
\text { Activity }\end{array}$ & $\begin{array}{l}\text { Financing } \\
\text { Activity }\end{array}$ & Total & $\begin{array}{l}\text { Operating } \\
\text { Activity }\end{array}$ & $\begin{array}{l}\text { Financing } \\
\text { Activity } \\
\text { Activity }\end{array}$ & $\begin{array}{l}\text { Total } \\
\text { Activity }\end{array}$ & $\begin{array}{l}\text { Operating } \\
\text { Actal }\end{array}$ \\
\hline $2011-12$ & 60.98 & -11.73 & 49.25 & 89.29 & -336.93 & -247.64 & -98.47 & 6.98 & -91.49 \\
\hline $2012-13$ & 33.16 & -1.37 & 31.79 & 819.24 & -321.28 & 497.96 & 41.61 & -194.60 & -152.99 \\
\hline $2013-14$ & 14.76 & -26.19 & -11.43 & -136.78 & -1419.04 & -1555.82 & -70.37 & 18.64 & 51.73 \\
\hline
\end{tabular}

Table 3 shows the year wise details of the net cash flows from the operating activities and financing activities and its total from 2011-12 to 2013-14. The total net cash flows of Maharashtra Scooter ltd shows a decreasing trend during the above said period. It was $49.25 \mathrm{crore}$ in 2011-12 decreased to negative cash flows of Rs.-11.43crore in 2013-14.

Similarly TVS Srichakra's total net cash flows were insufficient as it shows negative cash flows in 2011-12 and 2012-13 i.e-91.49crore and -153.08crore respectively. As far as Tata Chemical ltd is concerned the net cash flows was deemed to good in 2012-13 as it has 497.96crore of positive cash flows but beginning and end of the study period net cash inflows of company was totally bad situation.

From the above table it is clear that in the total net cash flows, operating cash flows contribution was vital in its total cash flows and financing activity cash flows are not significant. In the study period all sample units selected for the study has cash outflows from financing activity expect in 2013-14 by TVS srichakra.

\section{ANALYSIS OF CASH POSITION}

Cash in hand and cash at bank is the most liquid asset as compared to other assets in the balance sheet of the company. Analysis of cash position ensures the analysts the company's cash position, sources of cash and uses of cash, surplus and deficit of cash at the end of the financial year. This helps to keep the optimum level of cash balance. Idle cash balance dose not earn any return so company should ensure minimum cash balance in hand. Following table4 and table 5 gives the level of cash position and its equivalents and net increase or decrease in the cash during study period i.e. from 2011-12 to 2013-14. The quantum of cash position to be maintained depends on size of business and its level of operation. 
Table 4: Table Showing Comparative Cash Position (Rs. In Crores)

\begin{tabular}{|l|l|l|l|l|l|l|l|l|l|}
\hline Years & Maharashtra Scooter & \multicolumn{2}{l|}{ Tata Chemical Ltd. } & \multicolumn{2}{l|}{ TVS Srichakra } \\
\hline & $\begin{array}{l}\text { Cash At } \\
\text { End }\end{array}$ & $\begin{array}{l}\text { Cash At } \\
\text { Beginning }\end{array}$ & $\begin{array}{l}\text { Net } \\
\text { Inc/Dic }\end{array}$ & $\begin{array}{l}\text { Cash At } \\
\text { End }\end{array}$ & $\begin{array}{l}\text { Financing } \\
\text { Activity }\end{array}$ & $\begin{array}{l}\text { Net } \\
\text { Inc/Dic }\end{array}$ & $\begin{array}{l}\text { Cash At } \\
\text { End }\end{array}$ & $\begin{array}{l}\text { Cash At } \\
\text { Beginning }\end{array}$ & $\begin{array}{l}\text { Net } \\
\text { Inc/Dic }\end{array}$ \\
\hline $2011-12$ & 7.43 & 3.53 & 3.90 & 965.09 & 1079.55 & -114.46 & 5.61 & 5.13 & 0.48 \\
\hline $2012-13$ & 31.67 & 7.43 & 24.24 & 1091.98 & 891.85 & 200.13 & 44.89 & 5.61 & 39.27 \\
\hline $2013-14$ & 14.55 & 31.67 & -1767 & 891.85 & 798.76 & 93.09 & 7.94 & 44.89 & -36.95 \\
\hline
\end{tabular}

Table 4 gives the comparative cash position of selected samples units. It's cash at the beginning, cash at the end along with net increase or decrease in cash during the period under research. In the year 2012-13 all three selected units generated highest cash inflows as it seen in the table that Tata Chemical Ltd capable to increase net cash Rs.200.13 crore, TVS Srichakra increased its cash position at the end of the year by Rs.39.27crore followed by Rs.24.24crore by Maharashtra Scooter ltd. If company analysis is done regarding net increase or decrease in cash position, Maharashtra Scooter ltd was not stable in ensuring the increase in cash position. A net decrease of Rs 17.67Crore was experienced by the company. Tata chemical Ltd was also unable to increase it closing cash balance in 2011-12 over its opening balance i.e. net decrease was Rs.114.46crore. TVS Srichakra is able to ensure to increase in its cash position during the study period.

Table 5: Table Showing Comparative Net Increase/Decrease in Cash and Equivalent (Rs. In Crores)

\begin{tabular}{|l|l|l|l|l|l|l|}
\hline \multirow{2}{*}{ Years } & Maharashtra Scoter & \multicolumn{2}{|l|}{ Tata Chemical Ltd. } & \multicolumn{2}{|c|}{ TVS Srichakra } \\
\cline { 2 - 7 } & $\begin{array}{l}\text { Net Cash } \\
\text { Flow }\end{array}$ & $\begin{array}{l}\text { \%et } \text { Change } \\
\text { Flow }\end{array}$ & $\begin{array}{l}\text { \% of } \\
\text { Change }\end{array}$ & $\begin{array}{l}\text { Net } \\
\text { Cash } \\
\text { Flow }\end{array}$ & \% of Change \\
\hline $2011-12$ & 3.90 & -- & 93.09 & -- & 0.48 & -- \\
\hline $2012-13$ & 24.24 & $52.15 \%$ & 200.13 & $114.98 \%$ & 39.27 & $808.12 \%$ \\
\hline $2013-14$ & -17.12 & -114.46 & $(157.19 \%)$ & -36.95 & $194.09 \%$ \\
\hline
\end{tabular}

From the table 5, it can be seen that the percentage of change in cash position over its previous year by all three selected sample units was said to be good. TVS Srichakra made a record in its history of $808.12 \%$ increase in cash position to its previous year in the year 2012-13, followed by Tata Chemical limited negative $114.98 \%$ and $52.15 \%$ by Maharashtra Scooter in the same year. In 2013-14 growth percentage of cash was negative by all selected units.

\section{SUGGESTIONS}

The following are the suggestions based on the study conducted during 2011-12 to 2013-14. The analysis of liquidity position by all company was weak. Company should ensure liquidity position by investing sufficient of funds in working capital. 
The study also reveals that cash flows from investing activity were not good. It is recommendable to company to ensure maximum allocation of funds in long term assets and projects which are profitable.

It is strongly recommended to company that it should control its operating costs by means of actions which results in increasing in net profit before tax.

\section{CONCLUSION}

A privately owned enterprise refers to a commercial enterprise that is owned by private investors, shareholders or owners (usually collectively, but they can be owned by a single individual), and is in contrast to state institutions, such as publicly owned enterprises and government agencies. Private enterprises comprise the private sector of an economy. An economic system that 1) contains a large private sector where privately run businesses are the backbone of the economy, and 2) business surplus is controlled by the owners, is referred to as capitalism. This contrasts with socialism, where industry is owned by the state or by all of the community in common. The act of taking assets into the private sector is referred to as privatization. The goal of private enterprise differs from other institutions, the major difference being private businesses exist solely to generate profit for the owners or shareholders.

\section{REFERENCES}

[1] "Tata Chemicals working on a green makeover - Corporate News". Livemint.com. 8 September 2009. Retrieved 16 July 2010, BSE 2009-2010 Data.

[2] Br Natarajan. "BITS Pilani and Tata Chemicals Join Hands for HRD”. Indiaprwire.com. Retrieved 16 July 2010.

[3] "TCL buys 25\% stake in urea complex in Africa for $\$ 290$ mn. 11 April 2010.

[4] "Tata Chemicals Ltd. (878472): Company Description _ Business Week. Investing.businessweek.com. 24 May 2010. Retrieved 16 July 2010.

[5] "Contact us". Tata Chemicals. 30 November 2008. Retrieved 16 July 2010.

[6] “Tatas acquire General Chemical of US for \$1 b”. The Hindu Business Line. 1 February 2008. Retrieved 16 July 2010. 